\title{
Malnutrition in Developing Countries: Role of Agriculture and Trading
}

\author{
Luís A. Cardoso ${ }^{1, *}$, Jorge Ferrão ${ }^{2}$, Tito H. Fernandes ${ }^{3}$ \\ ${ }^{1}$ CIISA, Faculty of Veterinary Medicine, Lisbon University, Lisboa, Portugal \\ ${ }^{2}$ The Vice Chancellor's Office, Universidade Pedagógica, Rua João Carlos Raposo Beirão 135, Maputo, Moçambique \\ ${ }^{3}$ ACIVET, Faculty of Veterinary Medicine, Lisbon University, Lisboa, Portugal \\ *Corresponding author: alfarocardoso@fmv.ulisboa.pt
}

\begin{abstract}
The changeable history of the fight against hunger is as old as humanity whose populations had to adapt again and again to changing environmental conditions, epidemics and other adversities. For the first time since the beginnings of agriculture, humanity now has the means at its disposal to overcome world hunger. Malnutrition remains one of Sub-Saharan Africa's most fundamental challenges for improved human development. It is important to recognize the links between malnutrition, poverty and, at the aggregate level, broad economic growth and national development, namely agrarian production. Presently one person in four goes hungry. In Sub-Saharan Africa, the modest progress achieved in recent years up to 2007 was reversed, with hunger rising $2 \%$ per year since then. Progress towards the Millennium Development Goals 1 (MDG 1) target, is assessed not only by measuring undernourishment, or hunger, but also by a second indicator - the prevalence of underweight children under five years of age. A vast amount of International Organizations deal with this subject and publish comprehensive reports not only on estimates on the progress already achieved, but also identifying remaining problems, providing guidance on which policies should be emphasized in the future. However, their targets remain almost unchanged. The aim of the present short review is to enhance the need for improved agriculture productivity and trading systems closely related with persistent malnutrition.
\end{abstract}

Keywords: malnutrition, undernourishment, food insecurity, trading systems

Cite This Article: Luís A. Cardoso, Jorge Ferrão, and Tito H. Fernandes, "Malnutrition in Developing Countries: Role of Agriculture and Trading." Journal of Food Security, vol. 5, no. 6 (2017): 248-258. doi: $10.12691 / \mathrm{jfs}-5-6-5$.

\section{Introduction}

Human nutrition describes the processes whereby cellular organelles, cells, tissues, organs, systems, and the body as a whole obtain, and use, the necessary substances obtained from foods (nutrients) to maintain structural and functional integrity. This process is complex and, understanding it, as well as the other factors that affect how humans obtain and utilize foods and nutrients from a molecular to a societal level, requires integrated knowledge across a spectrum of basic and applied science.

Human nutrition involves the metabolic and physiological responses of the body to diet and the provision to obtain the materials necessary to support life. In general, people can survive for two to eight weeks without food, depending on stored body fat and muscle mass and water availability. Survival without water is usually limited to three or four days.

The world is still blighted by hunger, with some countries having almost half their population unable to get enough food on a daily basis. Lack of food remains a serious problem globally, with some 793 million people estimated, the majority of which are in Africa and Asia, to be undernourished (in terms of dietary energy supply) in the period 2010-12, representing $12.5 \%$ of the global population or one in eight people.

The majority of these, ca. 750 million, are situated in developing countries, in which the prevalence of undernourishment is calculated at $14.9 \%$ of the population $[1,2]$. This number has fallen over the last decade, mainly in Asia, with some nations managing to more than half undernourishment during this century. Strangely, the World Bank does not mention countries such as Yemen, Mozambique, Angola and several others probably not studied but important for this snapshot (Figure 1).

Some 60 years elapsed, millions of people involved and billions of US\$ spent, several UN organizations and many others as leaders on huge efforts, have pledged as their vision and mission reducing rural poverty, fighting famine and malnutrition, however the result today is not still in general significant in Africa and South America. This number has however fallen successfully by 167 million over the last decade, mainly in Asia, with some nations managing to more than half undernourishment during this century, specifically in some regions of South America, the east and south-eastern regions of Asia, the Caucasus and Central Asia, and the northern and western regions of Africa. At the same time, world agriculture is producing more food than ever before, both in total numbers as well 
as on a per capita basis, despite the fact that the world population is growing.

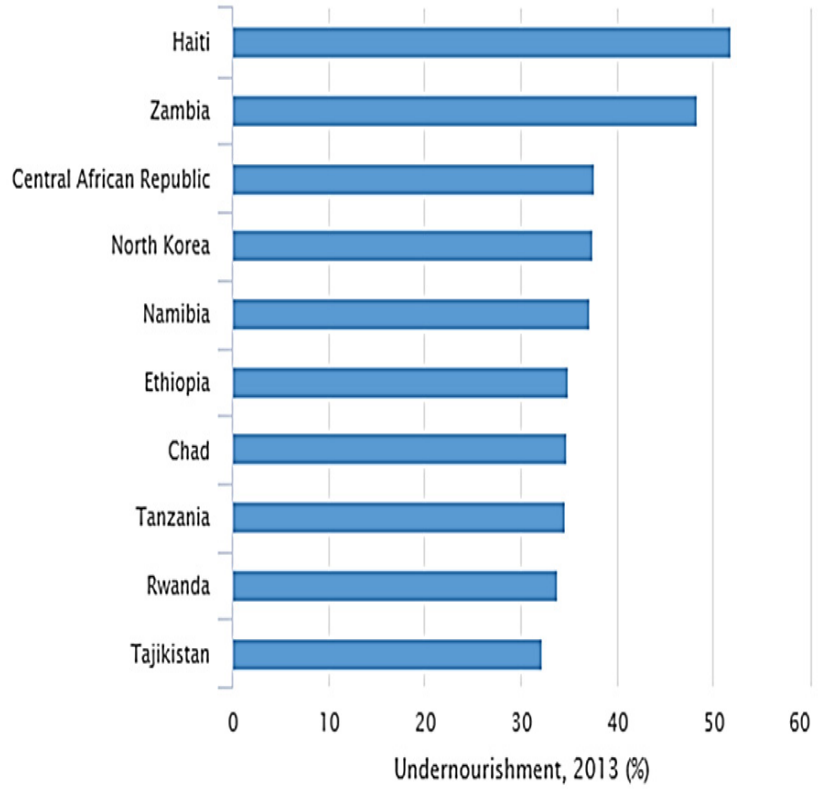

Figure 1. Under-nutrition in the world [2]

For half of the developing regions as a whole, the two indicators of MDG $1-$ the prevalence of undernourishment and the proportion of underweight children under 5 years of age - have both declined; undernourishment declined faster than the rate for child underweight, suggesting room for improving the quality of diets, hygiene conditions and access to clean water, particularly for poorer population groups.

The basic needs approach is one of the major methods to the measurement of absolute poverty in developing countries. It attempts to define the absolute minimum resources necessary for long-term physical well-being, usually in terms of consumption goods. The poverty line is then defined as the amount of required to satisfy those needs. Although food/water seems to be the most important of the three basic needs of man, besides shelter and clothing, most of the developing world is still faced with the problem of malnutrition.

This problem seems to affect specific groups of people rather than the whole population. Achieving household food and nutrition security requires co-ordination among local authorities and institutions that can or should support food insecure groups. It enables households to maximize food security and nutrition efforts with existing household local supplies, while also striving to increase these homegrown resources.

\section{World Agriculture}

More than $90 \%$ of the 580 million farms worldwide are managed by an individual or a family, relying predominately on family labour. These farms produce more than $80 \%$ of the world's food, in terms of value.

The United Nations had already declared food an inalienable human right in 1948. However, today, people affected by hunger still do not have effective means of enforcing their right to adequate food and freedom from hunger. If they really wanted to, all governments worldwide could ensure that their citizens have enough to eat.

Global cereal supplies are likely to remain abundant in the 2017/18 season (Figure 2). If the harvest was used entirely and as effectively as possible as food, it could already feed 12 to 14 billion people [3]

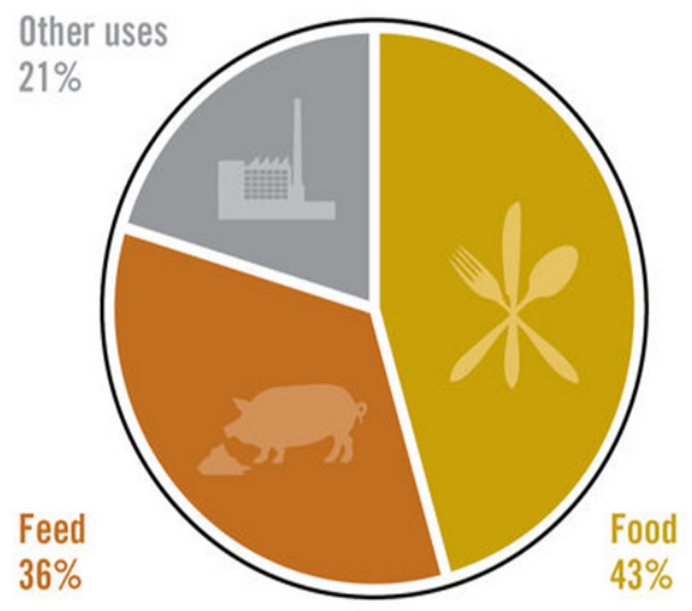

Figure 2. World cereal production [3]

The global number of undernourished people published by the FAO each year refers to an average from the past three years and is based on complex assumptions and calculations, as well as national statistics of different quality and independence. Many of these assumptions have proved to be highly flexible.

In 2009, FAO [4] warned that more than a billion people were suffering from hunger; in 2010 the number was 925 million [5]. In 2014, the FAO revised its methodology [6]. The number of undernourished then dropped to 868 million people, reaching 842 million in 2013 and 795 million in 2015 [7,8]. The changeable history of the fight against hunger is as old as humanity whose populations had to adapt again and again to changing environmental conditions, epidemics and other adversities.

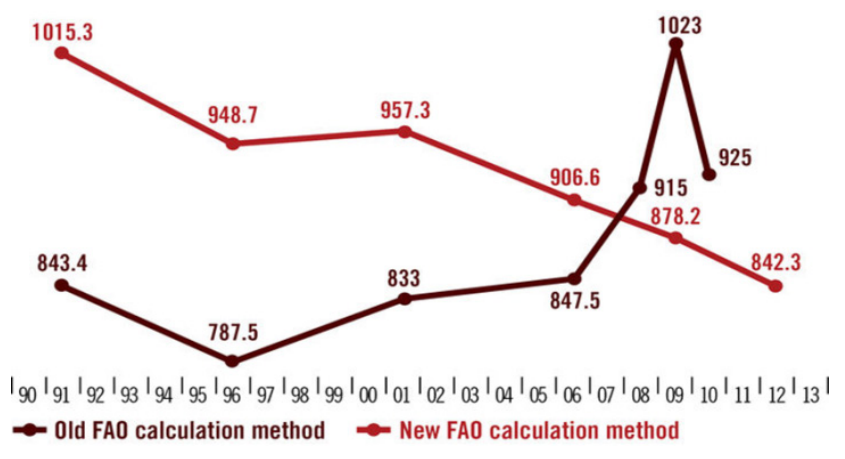

Figure 3. Comparison of FAO methods of calculating undernourished people [6]

These new estimates by FAO [6] now capture food losses but they also assume that people, on global average, are less physically active and somewhat smaller, and that distribution inequalities are less marked than previously thought. These and other assumptions changed, as if by magic, the curves depicting the number of hungry people, which now no longer tend upwards but downwards 
(Figure 3). The most important basis for the calculation of the number of undernourished is the daily energy requirement of a person and consumption estimated.

The analysis presented in this short review demonstrates the expansion in the gap between agricultural output and its availability to a vast proportion of the population. It also shows that statistics can conceal the annual increase of millions of undernourished people mainly due to obstacles in food access and deficient market systems.

We highlight the need to review national and international policies so as to mitigate significant problems in food access pathways, and the essential requirement to change the developed countries' protectionist trade rules, which are depressing African markets in developing regions.

\section{Food Security}

\subsection{Food Security Concept}

Hunger and malnutrition, in times of plenty, are pervasive problems that affect millions of people in the world today, especially in developing countries where some 5.9 million children under the age of five die of malnutrition-related causes every year [9]. Undernourishment means that a person is not able to acquire enough food to meet the daily minimum dietary energy requirements, over a period of one year. FAO [8] defines hunger as being synonymous with chronic undernourishment (Figure 4).

9

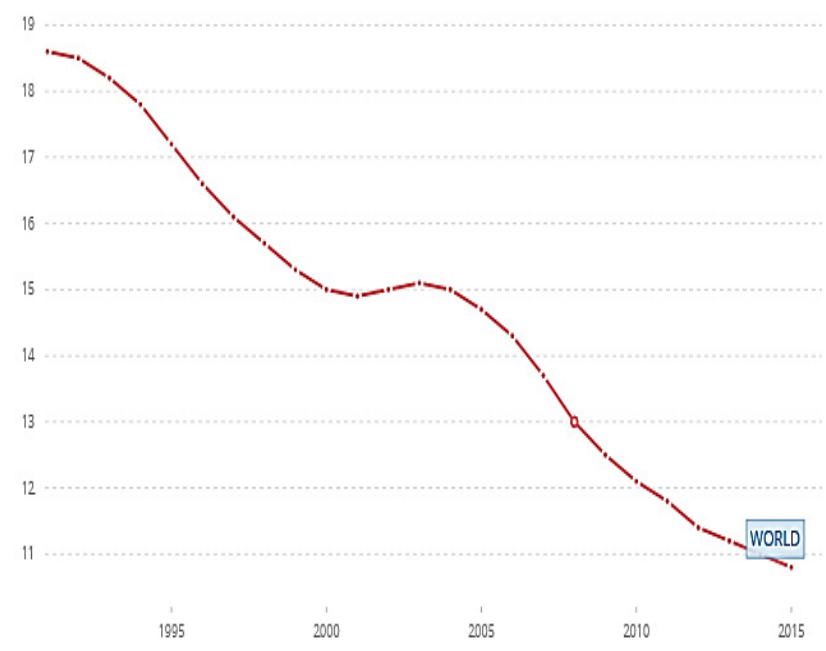

Figure 4. Prevalence of world undernourishment (\% of population) [2]

Concepts of food security have evolved in the last thirty years to reflect changes in official policy thinking [10] [11]. The term first originated in the mid-1970s, when the World Food Conference [12] defined food security in terms of food supply. Food security can be considered as an end result of options for development strategies including land and agriculture, health, education, transport, labour, research and other mainstream policies conditioning food production and availability.

This is an issue that has been thoroughly studied and debated by international, regional and national fora with in depth holistic approaches [13]. The implementation of rural development projects, specifically aiming at Africa, with special reference to Sub-Saharan Africa (SSA) has, within the last 20 years, involved billions of US\$ from external aid programmes, as this continent has been considered the most deprived area in terms of food availability to its population [14].

\subsection{Undernourishment Impacts}

New Partnership for Africa's Development (NEPAD of African Union) Comprehensive Africa Agriculture Development Programme (CAADP) - was Africa's policy framework for agricultural transformation, wealth creation, and food strategy - , has foreseen investments of US\$251 billion for the period 2002 to 2015 (approximately US\$ 18 billion per year), for undernourishment mitigation and for agriculture productivity increase [15]. It was considered that agriculture was Africa's surest path to prosperity. Achieving meaningful agriculture transformation requires strong coordination between partners in a countries-led process.

Of this investment, US\$ 7 billion annually (39\%), derives from public domestic sources in Africa, US\$ 6.3 billion (35\%), comes from assistance from donors. Private investment and commercial loans was to cover the remaining US\$ 4.7 billion. However this budget has not been easy to achieve for the estimated total annual government expenditures on agriculture in Africa in the late 1990s were about US\$ 6.2 billion $[16,17]$.

To add to this difficulty through the 1990s the major bilateral and multilateral donors annually committed globally only about US\$ 8 billion to agriculture [18]. The application of science and technology to agriculture requires extensive coordination across many actors and sectors. It is essentially a political process, and political leadership is essential [19].

Research and Development efforts include programmes and institutions such as the Millennium Project, FAO, IFAD, the CGIAR centres (e.g. ICARDA, CIAT, ICRISAT, IFPRI, IITA, ILRI, IFPRI), WTO , EU, NEPAD, FARA, CORAF/WECARD, ASARECA, CORAF/WECARD,SADEC, NGO's and other relevant partners acting in bilateral or multilateral programmes. Although there are encouraging outcomes from many of these initiatives, the absolute number of undernourished population in Africa [20] during the last 20 years has increased by $18.6 \%$, from 182 million in 1990 to 216 million in 2011, including acute hunger crises facing 30 to 40 million Africans annually [21].

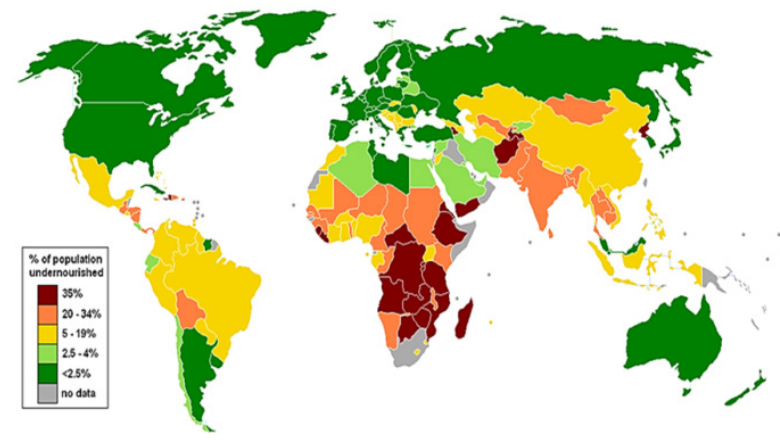

Figure 5. World map indicating the percentage of global undernourishment (2008) [22] 
FAO Hunger Map from 1970 to 2003 [22] show that in 1970 all of Africa appeared to have an issue of undernourishment. As time went by it seems like only the central regions have a malnourishment issue. The world map in 2015 (Figure 5) is clear in illustrating the distribution of undernourishment.

As a result, about a third of African children are stunted in their growth and face physical and cognitive challenges from which their better-fed peers are free. It has been estimated that every minute, eight under-5 children die in Sub-Saharan Africa [23]. Of the 46 countries in the African Region, 36 have under-5 mortality rates (U5MRs) of above 100 per 1000 live births; 8 have U5MRs of at least 200 per 1000 live births; 5 countries have had static U5MRs in the past fifteen years, while in 9 countries the U5MRs have reversed [21].

Two thirds of the under-5 deaths in the African Region are due to preventable causes [21]. The chief causes of death are neonatal conditions and acute respiratory infections, mainly pneumonia, malaria, diarrheal diseases, measles and HIV/AIDS, most of which are complicated by malnutrition that accounts for one third of all deaths in children under five years. Under-5 deaths, most of which occur in the African Region, increased to $43 \%$ globally in 2005 from $31 \%$ in 1990. According to WHO (2014), an estimated 10.6 million under-5 children die each year, 4.6 million of whom die in Africa.

Food insecurity in Africa threatens the lives of millions of vulnerable people, especially displaced persons and people with HIV/AIDS [21]. Undernourishment is directly or indirectly responsible for 3.5 million child deaths every year, and at least $35 \%$ of the disease burden in under- 5 children. Sub-Saharan Africa has one of the highest prevalence of low birth weight ranging from 7- 42\%. Exclusive breastfeeding rate is low and complementary foods are inadequate and inappropriate in the region. Maternal nutrition increases the risk of death of the mother at birth and may be associated with about $20 \%$ of maternal undernourishment [24].

Strangely, this hunger map of Africa and the Orient (Figure 6) do not reflect however the situation in Yemen and South Sudan.

In brief, malnutrition is the major risk factor underlying over $28 \%$ of all deaths in Africa (ca. 2.9 million deaths annually). These indicators show an even worse performance in SSA, with an increase of $20 \%$ of undernourished population (from 176 million in 1990 to over 211 million in 2011 [20]. Considering all human resources and financial efforts involved in mitigating undernourishment in Africa, with special reference to SSA, it can be considered that there is no evidence of an overall success history (Figure 7).

The complex requirements of development strategies imply the presence of a wide range of components that must be considered in a case by case analysis that cannot be underestimated. Therefore it is not possible to find a 'silver bullet' that would solve the problems behind the resilient African undernourishment. This a main conclusion of many of the fora that have debated the issue such as the IFPRI All African Conference 'Assuring Food and Nutrition Security in Africa by 2020', held in April 2004 in Kampala [13].

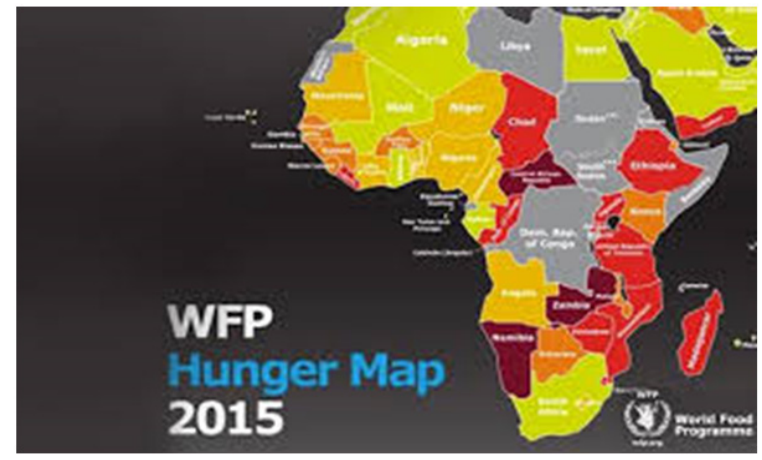

Figure 6. Hunger Map of Africa [25]

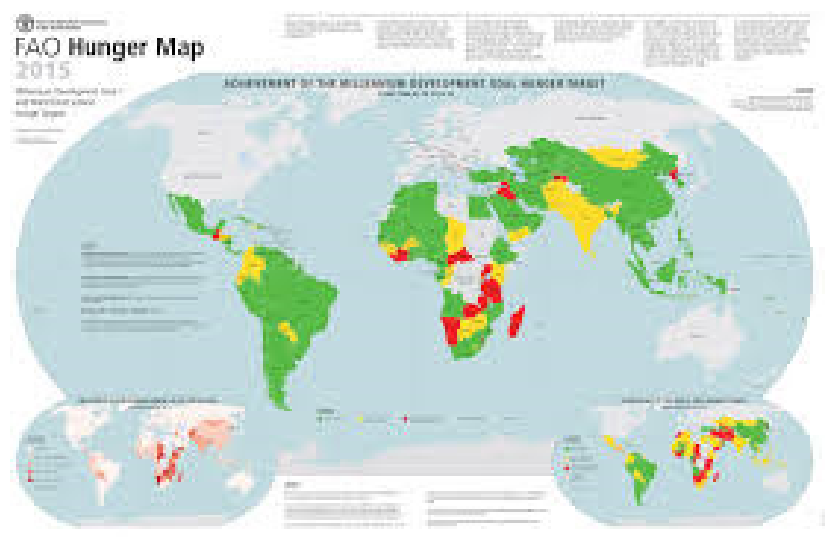

Figure 7. Prevalence of Undernourishment [26]

Much work remains to be done to eradicate hunger and achieve food security across all its dimensions. The list of factors - economic growth, agricultural productivity growth, markets (including international trade) and social protection - is by no means exhaustive.

\subsection{Progress towards the World Food Summit (WFS) and Millennium Development Goal (MDG) Targets in Sub - Saharan Africa}

Governments in Sub-Saharan Africa are under pressure to improve performance in the fight against food insecurity. While progress has been made towards achieving the WFS and the MDG targets, differences persist across sub-regions and individual countries. A commitment to an inclusive, national programme for food security and nutrition will usually require new institutional arrangements to bring together the various actors within government, the private sector, and civil society. There has been a link between improvement in food security and nutrition, and country performances in terms of government effectiveness and governance and indeed those countries which achieved one target and made progress in the other have also improved their performance in terms of controlling corruption and improving government effectiveness.

The progress towards reaching the UN's food security targets in some countries has been hampered by challenging global economic conditions, extreme weather events and political instability. The absolute number of people who suffer from hunger remains unattainable, whereas the Millennium Development Goal was narrowly missed (Figure 4). 

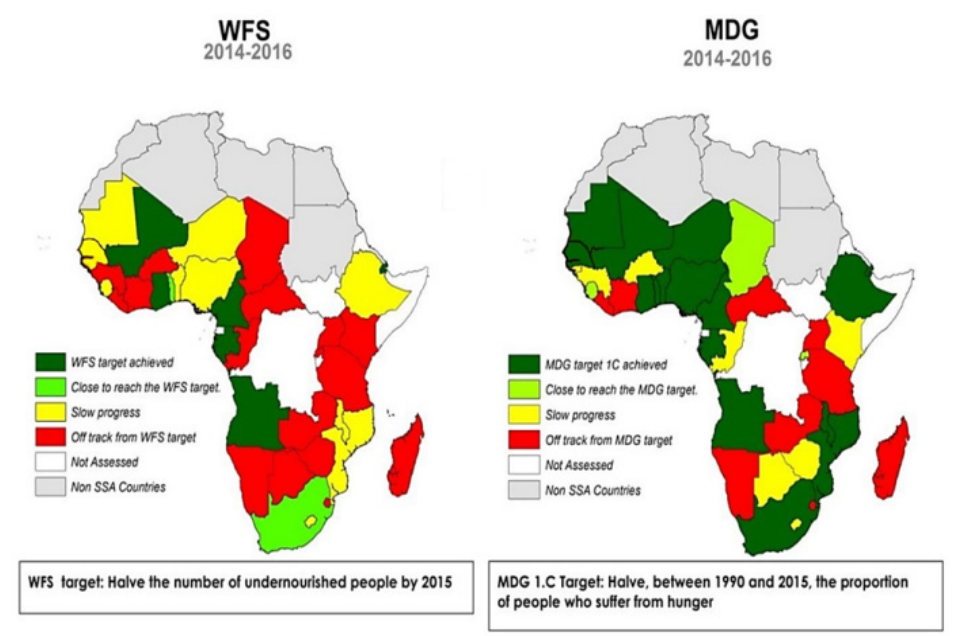

Figure 8. Progress towards the World Food Summit (WFS) and Millennium Development Goal (MDG) targets in Sub-Saharan Africa (SSA) [7]

In Sub-Saharan Africa, there has been limited progress in reducing both undernourishment and child underweight. This suggests that all aspects of food security need to be tackled - including ensuring the availability of, and access to, more and better quality food, enhanced hygiene conditions and access to clean water - before significant progress towards improved food security can be made (Figure 8) [7].

\subsection{Role of Agriculture Production and Trading Systems in Rural Development}

Many authors emphasize the transversal importance of agriculture and trading of agrarian products as key issues when discussing food security problems [27]. This fact does not imply neglecting other development factors such as education, health, or transport facilities. On the contrary, in most cases poverty has its roots in very low agricultural productivities and on the lack, or on the distortion, of agricultural trading pathways that result in the absence or in the interruption of a chain value that would otherwise significantly increase agriculture's role in development, in particular, small farmers' income. Adding to this fact, subsistence farming still has a major role in family economy within SSA [28].

For many years almost all aid to agricultural development was concentrated in production techniques, underestimating the essential need to provide the rural developing world with the necessary means to market their products, let alone to do it in fair deals. And as is well known, low incomes generate vicious circles of poverty, lack of education and health care, which are trademarks of inequity and of underdeveloped societies. If these considerations or assumptions could be statistically supported, perhaps one of the 'bottle necks' on mitigating undernourishment with a 'cross continent' relevance could be highlighted, thus contributing to policy conceptions that could add efficiency to the implementation of development programmes.

Production and trading systems can be synthesized as two of the main components to be addressed when discussing food availability in developing countries. Production would include land accessibility and all the necessary technology to its correct use. Trading systems involve maintaining into the producer's interest the output chain value until it reaches, as far as possible, the final consumers. Acquiring production assets (e.g. seeds, fertilizers, tractors) in good negotiated conditions is also an important issue within trading systems.

\subsection{SSA Food Production and Consumption Levels}

To find out to what extent these two components are responsible for the increase in the number of undernourished people in Africa could provide an indication of priorities of where to invest resources. Agricultural trading systems have recently been included in funding budgets aimed at rural development in Africa [29].

For decades the main efforts were concentrated on upgrading agrarian production. Trading systems should now be a main target for undernourishment mitigation programmes showing objective arguments to depict it. Although the present approach is a regional one (Africa and SSA), a case by case (or country by country) analysis should always be done whenever necessary.

FAO (2013) was actually used as a statistical data base. Not all indicators from this data base refer specifically to SSA region. In these cases, SSA data was obtained considering western, central, eastern and southern African data, according to FAO (2013) country classification system. Data evolution corresponding to a twenty year interval concerning food security was analysed (Figure 9). Data from $1990 / 1992$, (according to available statistics) to 2011 was considered.

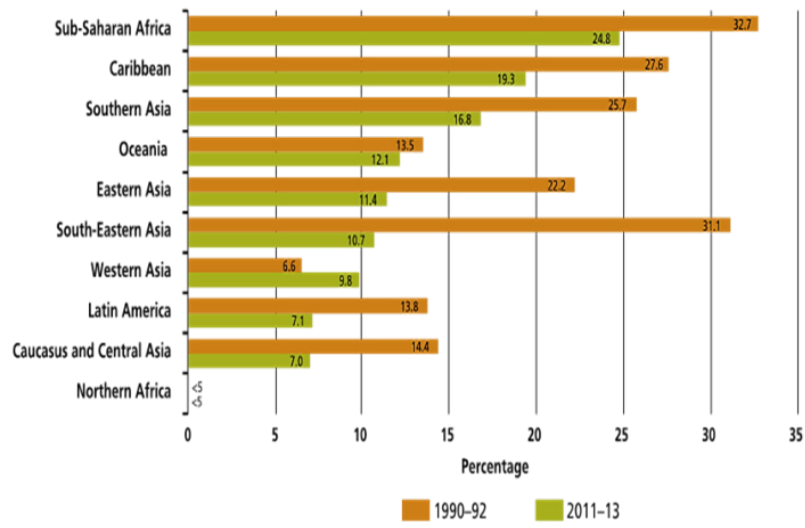

Figure 9. Undernourished people in selected world sub-regions [28] 
As shown in Table 1, population growth in SSA, within the analyzed period was $76 \%$, against $67 \%$ in the entire continent. A comparison of the evolution of population growth and production of relevant energy (e.g. cereals, roots and tubers) and protein suppliers (e.g. total meat or beans), value of agriculture production and undernourished population variation within the studied period shows that the increase in food production in the entire continent was higher than population growth.

In SSA, the overall production change matched population growth. When adding food imports to local production, three main staples have to be considered: cereals/tubers, meat and oils. The present study considered the import/export balance of cereal, roots and tubers, (representing $64 \%$ of share of dietary energy supply during the analyzed period meat and vegetable oils [20]. Protein intake in SSA changed from 1990 to 2011, to 50 to $57 \mathrm{~g}$ daily, respectively, representing about $11 \%$ to $12.6 \%$ of total average energy intakes. Thus, about $25 \%$ of energy requirements are covered by lipids, particularly vegetable oils. Considering that cereals are the unique important item in this balance (roots \& tubers import/export trades were less than $1 \%$ production levels), calculations from FAO (2013) showed that in SSA the cereal net imports were $8 \%$ and $26 \%$ of regional production for 1990 and 2011, respectively.

From our own calculations based on FAO (2013) data, meat trading balances in SSA were negligible, being only 0.2 and $0.4 \%$ of SSA production in 1990 and 2011, respectively, thus not significantly affecting energy intake (Table 1). Vegetable oil trading balances in 1990 and in 2013 increased by $1.6 \%$ and $2 \%$ over regional productions, respectively. Considering the energy densities of cereals and vegetable oils, respectively $4 \mathrm{Kcal} / \mathrm{g}$ and $8.1 \mathrm{Kcal} / \mathrm{g}$ and the partial energy contribution of imported carbohydrates $(26 \%)$ and fat (4\% due to energy density), the imported food energy sums up to $30 \%$ of the regional production.

As both carbohydrates and fat contribute to $89 \%$ of total energy intake as referred above, net energy of food imports accounted for $26.7 \%$ energy supply in 2011 (30\% $\mathrm{x} 89 \%$ ), which is $26.7 \%$ over the SSA regional production in that year. As calculated from Table 1, the rate of undernourishment decreased from 1990 to 2011 in the entire continent as well as in SSA, by $26 \%$ and $25 \%$, respectively, which equals the increase (over production) of imported food energy. Regional food production increment during this period matched population growth.

Thus it can be concluded that decrease in \% undernourishment in Africa and in its sub region (SSA) can be due mainly to imported food and not to increases in production or agricultural market upgrading.

The average African daily food supply per capita during this period increased by $12.7 \%$, from $2320 \mathrm{Kcal}$ to 2615 Kcal, well above the FAO undernourishment brake line of $1800 \mathrm{Kcal} /$ daily/capita [20] showing that inequity in access to food plays a major role in the continent. The average energy intake according to these statistics, represents about $28 \%$ over the FAO threshold for undernourishment $(1800 \mathrm{Kcal})$, showing that the actual food availability would be enough to solve under nutrition in SSA.

Within each of SSA sub-regions, daily food supply per capita was upgraded from $7 \%$ (Southern Africa) to $25 \%$ (Middle Africa). The lowest energy intake value refers to East Africa in 1992 (1861 Kcal/daily/capita) and the highest being $2920 \mathrm{Kcal} /$ daily/capita in 2011. This data does not explain the glooming reality of a continent in which although the percentage of undernourishment incidence is decreasing from $27.7 \%$ in 1990 to $20.9 \%$ in 2011 , there is an increase of about $20 \%$ in the absolute number of undernourished people (both in Africa and SSA).

Therefore, it can be seen that during the study period, the growth in African population has been matched by increase in food production and that the percentage decrease in the undernourished population is mainly due to food imports. It is also shown that the undernourished population increased by 34.7 million in this continent during the study period.

These figures indicate that although much has to be done in terms of improving agricultural production conditions and technologies in Africa, there are other limiting factors that must be dealt with. The data reflect an expansion in the gap between agricultural output and its availability to a vast proportion of the population. In fact statistics are presented, as they should, as averages (e.g. daily per capita energy intake) while concealing standard deviations. These include the annual increase of millions of undernourished people.

Table 1. Agriculture Production Value 2004-2006 [30]

\begin{tabular}{|l|c|c|c|c|c|c|}
\hline & \multicolumn{2}{|c|}{ Africa } & \multicolumn{2}{c|}{ Sub-Saharan Africa (SSA) } & \multicolumn{2}{c|}{$\%$ Change 1990-2011 } \\
\hline & 1990 & 2011 & 1990 & 2011 & Africa & SSA \\
\hline Population (Million) & 629,990 & $1,056,985$ & 484,353 & 853,872 & $67 \%$ & $76 \%$ \\
\hline Production of Cereals (tonnes) & $89,209,258$ & $156,054,640$ & $65,682,243$ & $115,309,323$ & $75 \%$ & $75 \%$ \\
\hline Production of Root \& Tubers (tonnes) & $3,053,952$ & $6,745,335$ & $3,052,072$ & $6,740,473$ & $120 \%$ & $120 \%$ \\
\hline Production of Meat (tonnes) & $8,738,590$ & $16,771,686$ & $6,602,754,4$ & $11,498,130$ & $91 \%$ & $74 \%$ \\
\hline Agriculture Production Value (x1000\$) & $104,357,445$ & $204,074,989$ & $78,255,000$ & $149,792,000$ & $95 \%$ & $91 \%$ \\
\hline Undernourished (Million) & 182 & 216 & 176 & 211,2 & $19 \%$ & $20 \%$ \\
\hline \% Undernourished & $27.7 \%$ & $20.9 \%$ & $33 \%$ & $24.4 \%$ & $-6.8 \%$ & $-8.6 \%$ \\
\hline
\end{tabular}




\section{National Government Food Production, Demand and Supply Policies}

\subsection{Food Access, Markets and Social Equity}

The need for agricultural production and productivity enhancement has been emphatically referred to in many relevant publications and has, for decades, been in the mainstream of Aid Programs in Africa, with national and international funds. Projections [13] indicate that food security in Africa will not significantly improve during the next 20 years, with cereal production annual growth ranging between 2 and $2.5 \%$.

As the continent's annual population growth is foreseen to change from the actual $2.7 \%$ to $2 \%$ in 2030 [30], the need to increase and improve agricultural production is very clear considering the context of the following statistics. According to FAO (2009a) poverty reduction progress has not been uniform and apparently it was interrupted during the current crisis. While relevant improvement was recorded in China, Indonesia, India, Pakistan, Brazil, Mexico and South Africa, Sub-Saharan Africa as a whole saw a large increase in the number of people living in absolute poverty and only a small decrease in the poverty ratio.

Indeed, considering the supply and demand for food and feed and excluding any eventual growth in demand for biofuels, the prevalence of chronic undernourishment in developing countries would decline to about $5 \%$ of their population by 2050 . But $5 \%$ of the developing countries' population in 2050 would still be 370 million people, an unacceptably high number. Moreover, the average hides differences between countries. Sub-Saharan Africa as a whole would still be at $7 \%$ prevalence of chronic undernourishment and some smaller countries could still have rates over $15 \%$. For almost 400 million people even the projected $70 \%$ growth in output of food and feed [32] will not guarantee that they will have access to adequate food.

Their access to food will require a proper socioeconomic framework to address imbalances and inequalities. Therefore, extra efforts of public policy will be needed, be it in terms of additional productive employment inside or outside agriculture, structural reforms creating a more equitable income distribution or targeted social safety nets. Moreover, food production must be carried out in a way that reduces poverty and takes account of natural resource constraints

The existence of hunger in a world of plenty is not only shameful and a violation of the human right to adequate food, hunger and malnutrition also entail large economic costs, severely compromising the productivity of individuals and, when more than $30 \%$ of the population are chronically undernourished as in many African countries, the growth of entire economies.

However the upgrading of agricultural production, by itself, cannot feed populations. Food access is very much dependent on the existence of an efficient market system and of social equity leading to policies providing basic public goods. Both components, market system and social equity, are highly conditioned by political options. And it appears that, in general, present options are not proving to be satisfactory.
In fact, they are actively contributing to increasing the absolute number of undernourished people across the African continent. These failures of governance include conflicts, which exacerbate poverty. But they are also caused by international institutions, for instance the ones implementing developed countries' protectionist trade policies that for sure depress African markets.

In a broad sense, the concept of marketing systems integrates postharvest handling and storage, marketing activities, working arrangements for collection of farm products, wholesaling, agro-processing, retailing, and exporting. Therefore, key requirements include infrastructure and transport networks, market information, trade credit, quality and safety standards, and contract arrangements.

As most of SSA agriculture is based on small or family farms, farmer associations or cooperatives are essential development instruments. The financial and human resources invested in this component have been far below their level of need. As they require clear political options, it is not difficult to see why and how these issues have not been dealt with, in spite of their obvious relevance to undernourishment mitigation and rural development.

\subsection{Past Experience and the Future of Value Chains}

It is however very encouraging that agricultural market and trading issues are being discussed in important fora in a very comprehensive way. In the case of some African export crops, e.g. cotton, sugar, coffee and cocoa, the supply chains have achieved remarkable efficiency. But the paradox is that the best market chains in SSA are for agricultural imports, with the risk of undermining African farmers' production efforts.

Organizing agricultural market systems imply providing extension services, improved seeds and other production factors, marketing, credit, storage, subsidies for main inputs, stabilizing prices for producers and enhancing small farmers' association structures. These initiatives are not compatible with a paradigm of market liberalization programmes advocated by strong political lobbies and options which see the role of the public sector as a mere facilitator, and leaving the main market development issues to the private sector.

This view has produced very poor results wherever it has been applied, with the exception of high value added product supply chains. The public sector has a unique responsibility and duty to accomplish these tasks and gradually transfer part of them to cooperative or private initiatives, while ensuring an efficient and economic sustainability of the system.

The Green Revolution in Asia provided a good example regarding the advantages of a strong public commitment in organizing agricultural markets and also not to repeat mistakes that can prevent its sustainability. But one cannot transfer these experiences to Africa as people, traditions, national laws and many other factors are quite different.

Perhaps one of the statements produced in the IFPRI All African Conference "Assuring Food and Nutrition Security in Africa by 2020", held in April 2004, could synthesize the relevance of agricultural markets in mitigating undernourishment: "when dealing with livestock, if you manage to get supermarkets to buy from 
smallholders, you will probably have a much greater impact than if you improve the calving productivity rate by a few percentage points. We need to look at the whole value chain to understand where the inefficiencies are and where the opportunities are" [13].

\section{International Agricultural Trading Policies}

\subsection{WTO Has Yet to Succeed in Its Contribution to Mitigate Undernourishment}

Agricultural market systems, as any other commodity trading mechanism, are highly dependent on international trading policies regulating prices, and import and export taxes. Protectionism measures that developed countries apply to their agricultural producers and exporters also play an important role in market access.

The impact of trading agreements for all developing countries is of paramount importance as they have the capacity to interfere with economies and population welfare, which justifies WTO (World Trade Organization) as a global centre for multilateral agreements. This organization's main milestones enable one to perceive the extent to which international trading networks affect developing countries' agriculture.

The WTO has been the stage for successive treaties aimed at strengthening trading relationships that would contribute positively to the developing world. During the last 30 years amongst the various initiatives, the Uruguay Round in 1986 and the Doha Round in 2001 are highlighted as major Treaties designed to address main developing guidelines in international trading. The Uruguay Round, leading to the creation of WTO [31] was the 8th round of multilateral trade negotiations structured within the framework of the GATT.

The mandate of the Round was to extend GATT trade rules to areas not previously included and/or considered too difficult to liberalize, such as agriculture and textiles, and also to involve new areas such as services, investment policy, and trade distortions. The Round was implemented from 1995 to 2000 (2004 in the case of developing member countries).

The Uruguay Round was considered by developing countries as not paying sufficient attention to their special needs. Intellectual property and industrial tariffs were found to place many constraints on policy-making and satisfying human needs. The intensified mercantilist attitude of the GATT/WTO major powers, and the structure of the WTO that replaced GATT tradition of decision by consensus, caused imbalances that were not in favour of developing countries. In short, it failed to meet its objective of being constructive instrument for the Least Developed Countries.

\subsection{The Doha Development Agenda (DDA)}

The current trade-negotiation round of the World Trade Organization [32], the Doha Development Round or Doha Development Agenda (DDA) was inaugurated in November
2001. Its objective was to lower trade barriers around the world, facilitating global trade. In 2008, talks have stalled over different positions on major issues, such as agriculture, industrial tariffs and non-tariff barriers, services, and trade remedies. The most relevant divisions were between developed nations represented by the European Union (EU), the United States (USA), and Japan on one hand and the developing countries led by India, Brazil, China, South Korea, and South Africa, on the other.

There is also considerable disagreement between the EU and the USA about their maintenance of agricultural subsidies considered as real trade barriers [33].

The Doha Round was inaugurated with a ministeriallevel meeting in Doha, Qatar, in 2001 which was followed by other ministerial meetings in Cancun, Mexico (2003), and Hong Kong (2005). Subsequent negotiation sessions took place in Paris, France (2005), Potsdam, Germany (2007), and Geneva, Switzerland (2004, 2006, 2008); the 2008 meeting broke down after failing to reach agreements on agricultural import rules mostly between the USA, China, and India.

In the Bali Ministerial Declaration on December 2013 [34] for the first time some success was achieved concerning bureaucratic barriers to commerce regarding only a small part of the Doha Round agenda. However to date (2017), the future of the Doha Round is still not certain. Heavy criticisms have been voiced concerning the failure of Doha rounds on enhancing developing countries' economies.

As an example, the following arguments were pointed out: $\$ 47$ billion were paid in subsidies to rich-country producers since 2001 creating barriers for the 15 million cotton farmers across west Africa trying to trade their way out of poverty; about 5 million of the world's poorest farming families have been forced out of business and into deeper poverty because of those subsidies; WTO [35] members have failed to agree in how to reduce the huge subsidies paid to rich world farmers, whose overproduction continues to threaten the livelihoods of developing world farmers; WTO has also failed to clarify the deliberately ambiguous rules on concluding trade agreements that allow the poorest countries to be manipulated by the rich states; in Africa, in negotiations with the EU, developing countries have been forced to eliminate tariffs on up to $90 \%$ of their trade because no clear rules exist to protect them; the rules for developing countries, known as 'special and differential treatment rules', were meant to be reviewed to make them more precise, effective and operational [35].

However WTO has failed to work through the 88 proposals that would fill the legal vacuum; the WTO pledged to improve access to its expensive and complex legal system, but did not do so. In 15 years of dispute settlement under the WTO, 400 cases have been initiated. No African country has acted as a complainant and only one least developed country has ever filed a claim; one of the WTO's five core functions agreed at its inception in 1995 was to achieve more coherence in global economic policy-making; the WTO failed to curb the speedy increase in the number of protectionist measures applied by $\mathrm{G} 20$ countries in response to the global economic crisis over the past two years - despite G20 leaders' repeated affirmations of their 'unwavering' commitment to resist all forms of protectionist measures; the WTO makes most 
of its decisions by consensus - and achieving consensus between 153 countries is nearly impossible.

But this highlighted another failure of the WTO: to break the link between market size and political weight that would give small and poor countries a voice in the trade negotiations; 18 years after the start of the Doha Development Round, governments have failed to make trade fair.

According to an ACP (African, Caribbean and Pacific ACP- Group of States) 'Study of Development from an ACP perspective in the WTO Doha Development Agenda Negotiations' [36] there has been no shortage of plausible reasons for the impasse in the negotiations of the Doha Agenda. Nevertheless, the following inter alia explanations were highlighted: different expectations from the Doha Round between developing and developed countries; irreconcilable agendas of development and mercantilism (as encapsulated in the reciprocity of the WTO); developed countries perceiving the Round merely as an opportunity to press for market opening by big developing countries such China, India and Brazil; shifts in relative economic power among WTO members; proliferation of bilateral and regional trading arrangements

\subsection{Regional Agreements. A Possible Way Out?}

In this study, ACP recommendations for a way out of the Doha impasse includes aligning the WTO focus on individual countries with the mainly regional focus of trade policy in ACP countries. It also highlighted that ACP countries should define an approach for developing commercial relations with the large and fast growing developing countries and emphasizing on how best they can achieve their objectives, e.g. through existing groups such as the LDCs (Low Development Countries).

Ironically, the Doha Round was launched as a Development Round. So far, the WTO efficiency profile seems to be in line with all, or at least much, of the criticism to which it has been subjected to. WTO failure to address main developing country issues, in particular the ones concerning agriculture and trading is having practical consequences in depressing developing countries' markets, thus affecting agricultural production and food availability in these countries. This can explain the emphasis on regional trading agreements for developing countries, in particular the ones representing small economies, so as to attract investments and markets.

\subsection{Sustainable Food Security Efforts. From Principles to Practice?}

With over 500 new publications a year, the United Nations FAO employing thousands of people responsible for most (over 75-80\%) of its budget on staff and transports, provides nevertheless robust technical knowledge and global statistics, but impossible for a single person to digest all of the information. The total FAO Budget planned for 2016-17 is USD 2.6 billion. Of this amount, $39 \%$ comes from assessed contributions paid by member countries, while $61 \%$ will be mobilized through voluntary contributions from Members and other partners.

Undernourishment is also one of the main concerns of other relevant institutions. In 2009, within the FAO framework, the World Summit on Food Security produced the Declaration of the World Summit on Food Security [4]. The relevance of this document is the strategic commitment of FAO and the Summit to the drive against undernourishment, following five principles - The Five Rome Principles for Sustainable Global Food Security subscribing the following actions and programmes:

1. To invest in country-owned plans, aimed at channeling resources to well designed and resultsbased programmes and partnerships;

2. To foster strategic coordination at national, regional and global levels to improve governance, promote better allocation of resources, avoid duplication of efforts and identify response-gaps;

3. To strive for a comprehensive twin-track approach to food security that consists of: a) direct action to immediately tackle hunger for the most vulnerable and b) medium and long-term sustainable agricultural, food security, nutrition and rural development programs to eliminate the root causes of hunger and poverty, including through the progressive realization of the right to adequate food;

4. To ensure a strong role for the multilateral system by sustained improvements in efficiency, responsiveness, coordination and effectiveness of multilateral institutions;

5. To ensure sustained and substantial commitment by all partners to investment in agriculture and food security and nutrition, with the provision of necessary resources in a timely and reliable fashion, aimed at multi-year plans and programmes. Agriculture production trading and farmers associations or cooperatives should be considered as main instruments for rural development sustainability.

Each of these principles includes the description of actions that commit United Nations/FAO not only to support other institutions and initiatives in order to implement them, but also to commit the organization to practical programmes with relevant impacts on mitigating undernourishment. It would be too early at this moment, to evaluate the real benefits of these programmes. But the fact that they exist, and that they were designed and approved at such an important summit, is encouraging.

The FAO-World Summit Declaration, as comprehensive as it is, could include a reference on two important 'bottlenecks' or limiting factors in the implementation of development projects within the regions and countries affected by mal nutrition, which includes almost every SSA country in the African continent. One of them concerns the project sustainability after the period during which funds are available. Many of the projects stop their activity after this period, seriously affecting its results and aims.

As it is well known, a basic condition to avoid this common situation is the investment in a solid human resource and institutional local structure ultimately responsible for the project implementation. This includes, in the case of agricultural programmes, state extension services and also private organizations - farmers associations or representatives - acting on behalf of the target population of agricultural development projects.

The equilibrium between state and private institutions in project participation is a mandatory condition to success. The other chronically weak component of these projects is 
underestimating the complex, but rewarding, investment in fixing agricultural markets within a national or a regional level. This option has a strong political base. In our view it is not compatible with neo-liberal pathways endorsing the implementation of fundamental development strategies to private initiatives that always fail because they are amongst state obligations, and do not comply with short or medium time financial returns that private business seek for. Indeed they are a state endowment.

\section{Research \& Development Programmes}

Multilateral (e.g. CGIAR, FAO networks) and bilateral cooperation (e.g. DFID, CIRAD) in research for development are potentially powerful instruments allowing for valuable insights for scientific and technologic advances in agricultural productivity and capacity building in developing countries, particularly in Africa. Countless examples abound of successful research programmes concerning vegetal and livestock health and production issues, making the most out of new technologies in molecular biology using genomics, proteomics and metabolomics approaches. These research lines are of upmost importance as they strengthen the human and structural resources of African R\&D institutions.

But the use of scientific and technologic advances is entirely dependent on agricultural extension services capable of transferring new knowledge and practices to the field. Environmental matters concerning forestry, livestock and agriculture production, soil and water preservation should also be major research issues as their practical impacts on rural development are unquestionable. The efficiency of this work is a key element justifying R\&D investments, and it requires expertise, attention and responsibility, attending to the cultural, historical and structural profiles of the population, which justifies rural sociology as a research field as important as the more technical ones.

A competent sociological approach in technology transfer induces good practices and paves the way to a strong and productive relationship between extension services and the target population. It also facilitates a feedback mechanism informing scientists and technicians on results concerning practical experimental work and its impact on farmers and communities.

For these reasons, and due to the chronic underinvestment in agricultural extension services in most developing countries, it is suggested that this component of $R \& D$ could be considered as fundamental in the efforts for mitigating undernourishment. CGIAR, FAO, and some bilateral network programmes with African regional R\&D institutions, are integrating this issue. It is strongly believed that technology transfer and capacity building will contribute significantly to delivering the achievements promised by the investment.

\section{The Future}

Our understanding of what needs to be done to eradicate hunger and malnutrition has changed significantly over the past ten years. Earlier approaches that emphasized the expansion of volumes of agricultural commodities to be produced for the benefit of the food processing industry, and addressing hunger and malnutrition in developing countries by a combination of subsidised exports and food aid. This is now behind us. The focus today has shifted in four directions:

First, there is an insistence on strengthening the ability for poor countries to feed themselves.

Secondly, there is recognition of the need to design agricultural policies that would support the incomes of small-scale farmers, including their organizations and trading policies in order to ensure that these would contribute to rural development and to the reduction of rural poverty.

Thirdly, there is a broad recognition that we need to shift to more sustainable farming practices

Fourthly, we now acknowledge the need to place nutrition at the core of our efforts to rebuild food systems.

\section{Concluding Remarks}

Hunger and poverty are inextricably linked, robbing people of well-being, healthy and productive lives, and stunting the mental and physical development of future generations. Hunger, in times of plenty, is primarily a rural problem that can only be overcome locally in the long term. Accordingly, regional self-sufficiency with food is, wherever possible, the essential backbone of sustainable rural development. While the world has made enormous progress in reducing global poverty, there is still a great deal to be done. By 2050, the world's population is expected to grow to more than 9 billion people. This will require at least a 70\% (not $60 \%$ according to FAO) increase in agricultural production to feed all this population. Major attention has to be given specifically to food access and market systems in rural development programmes.

A more food-secure, nourished world, able to feed itself and the future, is essential to the long-term prosperity of individuals, communities, economies and nations. In May 2012, with African heads of state and G-8 leaders, global food security efforts were discussed and the New Alliance for Food Security and Nutrition was announced, a shared commitment to achieving sustained and inclusive agricultural growth and poverty reduction in Sub-Saharan Africa. The failure of many governments in the fight against hunger is often caused by corruption, incompetence, war and internal conflict. The arrogance and ignorance that urban elites display with respect to rural development present further problems.

\section{References}

[1] FAO, WFP, and IFAD (2012). The State of Food Insecurity in the World 2012. Economic growth is necessary but not sufficient to accelerate reduction of hunger and malnutrition. Food and Agriculture Organization of the United Nations, Rome. http://www.fao.org/docrep/016/i3027e/i3027e.pdf.

[2] World Bank (2015). Prevalence of undernourishment (\% of population)..http://data.worldbank.org/indicator/SN.ITK.DEFC.ZS

[3] FAO (2016). World Food Situation. FAO Cereal Supply and Demand Brief. http://www.fao.org/worldfoodsituation/csdb/en/. 
[4] FAO (2009). Declaration of the World Summit on Food Security. http://www.fao.org/fileadmin/templates/wsfs/Summit/Docs/Final Declaration/WSFS09_Declaration.pdf.

[5] FAO (2010). The State of Food Insecurity in the World Addressing food insecurity in protracted crises. ISBN 978-92-5106610-2. http://www.fao.org/docrep/013/i1683e/i1683e.pdf.

[6] FAO (2014). FAO Statistics Division Working Paper Series ESS / 14-05. Refinements to the FAO methodology for estimating the prevalence of undernourishment indicator. www.fao.org/economics/ess/ess-publications/workingpapers.

[7] FAO, IFAD and WFP. (2015).The State of Food Insecurity in the World 2015. Meeting the 2015 international hunger targets: taking stock of uneven progress. Rome. FAO.

http://www.fao.org/3/a-i4646e.pdf.

[8] FAO (2015). Regional overview of food insecurity: African food security prospects brighter than ever. Accra. FAO. ISBN 978-925-108781-7. http://www.fao.org/hunger/en/.

[9] WHO (2015). Children: reducing mortality. http://www.who.int/mediacentre/factsheets/fs178/en/.

[10] Clay E. (2002). Food Security: Concepts and Measurement, Paper for FAO Expert Consultation on Trade and Food Security: Conceptualizing the Linkages Rome, 11-12 July 2002. Published as Chapter 2 of Trade Reforms and Food Security: conceptualizing the linkages. Rome: FAO, 2003. http://www.fao.org/docrep/005/y4671e/y4671e06.htm.

[11] Heidhues F, Atsain A, Nyangito H, Padilla M, Ghersi G, and Le Valle JC. (2004). Development Strategies and Food and Nutrition Security in Africa: An Assessment. International Food Policy Research Institute. http://www.ifpri.org/category/publication-type/discussion-papers.

[12] UN (1974). Universal Declaration on the Eradication of Hunger and Malnutrition, United Nations.

http://www.ohchr.org/EN/ProfessionalInterest/Pages/EradicationO fHungerAndMalnutrition.aspx.

[13] IFPRI (2004). Assuring Food and Nutrition Security in Africa by 2020. IFPRI, Washington DC. Proceedings of an All-Africa Conference April 1-3, 2004, Kampala, Uganda. http://pdf.usaid.gov/pdf_docs/Pnadb908.pdf.

[14] ODI-Overseas Development Institute (2009). Poverty and poverty reduction in sub-Saharan Africa: An overview of the issues. https://www.odi.org/sites/odi.org.uk/files/odi-assets/publicationsopinion-files/860.pdf.

[15] Mbola B. (2008). "NEPAD summit to discuss global challenges facing Africa", BuaNews (SA Government), 15 April 2008. http://www.sabinetlaw.co.za/search/node.

[16] FAO (2002). Mobilizing the political will and resources to banish world hunger. Food and Agriculture Organization oh the United Nations, Rome. The World Food Summit - five years later. http://www.fao.org/docrep/004/Y1780e/Y1780e00.htm.

[17] World Bank (2003). World development indicators 2003. http://documents.worldbank.org/curated/en/973231468331252903 /World-development-indicators.

[18] FAO, IFAD, and WFP (2002). Reducing poverty and hunger: The critical role of financing for food, agriculture, and rural development. Rome. Paper Prepared for the International Conference on Financing for Development Monterrey, Mexico, 18-22 March 2002. https://www.wfp.org/sites/default/files/JointPaper.pdf.

[19] Bell V, Ferrão J and Fernandes TH (2017). "Nutrition, Food Safety and Quality in Sub-Saharan Africa". EC Nutrition 9.6 (2017): 243-255
[20] FAO (2013). FAO Statistical Yearbook: World food and agriculture, Food and Agriculture Organization of the United Nations, Rome. http://www.fao.org/docrep/018/i3107e/i3107e00.htm.

[21] WHO (2014). Regional Office for Africa. http://www.afro.who.int/en/clusters-a-programmes/frh/child-andadolescent-health/programme-components/child-health.htmldeaths

[22] FAO (2009a). How to Feed the World in 2050 - Food and Agriculture organization. www.fao.org/.../wsfs/.../How_to_Feed_the_World_in_2050.pdf.

[23] WHO (2011). Child mortality. Millennium Development Goal (MDG) 4

http://www.who.int/pmnch/media/press_materials/fs/fs_mdg4_chi ldmortality/en/.

[24] FAO and IFAD (2013). The State of Food Insecurity in the World 2013. The multiple dimensions of food security. FAO. http://www.fao.org/docrep/018/i3434e/i3434e.pdf.

[25] WFP (2015). The Hunger Map. https://www.wfp.org/content/hunger-map-2015.

[26] FAO (2015a). The State of Food Insecurity in the World 2015. http://www.fao.org/hunger/en/.

[27] FAO (2010). Food Security in Africa. Market and Trade Policy for Staple Foods in Eastern and Southern Africa. Edt. By Alexander Sarris and Jamie Morrison. http://www.fao.org/docrep/018/i0714e/i0714e.pdf

[28] IAASTD (2009). Agriculture at a Crossroads. International Assessment of Agricultural Knowledge, Science and Technology for Development, Sub-Saharan Africa (SSA) Report. ISBN 978-159726-538-6.

http://www.fao.org/fileadmin/templates/est/Investment/Agricultur e_at_a_Crossroads_Global_Report_IAASTD.pdf.

[29] Agriculture for Impact (A4I) (2010). European Donor Review Background and Rational. Imperial College, London, UK. http://ag4impact.org/publications/european-donor-reviewbackground-and-rationale/.

[30] African Development Bank Group (2012). Briefing Notes for AfDB's Long-Term Strategy Briefing Note 4: Africa Demographic Trends.

https://www.afdb.org/fileadmin/uploads/afdb/Documents/PolicyDocuments/FINALTrends.pdf.

[31] WTO (2014) Understanding the WTO: The Uruguay Round, World Trade Organization. http://www.wto.org/english/thewto_e/whatis_e/tif e/fact5 e.htm.

[32] WTO (2014) The Doha Round, World Trade Organization. http://www.wto.org/english/tratop_e/dda e/dda e.htm

[33] Hanrahan C and Schnepf R. (2006) 'WTO Doha Round: the agricultural negotiations', Congressional Research Service, Library of Congress. http://digitalcommons.law.msu.edu/facpubs.

[34] WTO (2013). 9th Bali ministerial declarations and decisions, https://www.wto.org/english/thewto_e/minist_e/mc9_e/mc9_e.htm.

[35] Walker A (2011). The WTO has failed developing nations. The Guardian.

http://www.theguardian.com/global-development/povertymatters/2011/nov/14/wto-fails-developing-countries.

[36] ACP (2011). Study of Development from an ACP perspective in the WTO Doha Development Agenda Negotiations. ACP. http://www.acp.int/content/study-development-acp-perspectivewto-doha-development-agenda-negotiations. 